\title{
EXPERT SYSTEM OF INDIVIDUAL PERFORMANCE EVALUATION OF EMPLOYEES
}

\author{
Lubomír Šooš ${ }^{1}$
}

\begin{abstract}
The monitoring of performance and positive motivation of employees has great influence on increasing the performance of institutions or workplaces. This applies to private, public and state institutions alike. One such institution is a public university. However, all available and so far developed systems make possible only partial employee evaluations. To our knowledge, no complex and objective individual assessment system is as yet available.

This was the main reason for which we decided to elaborate a completely new individual assessment system that makes possible the evaluation of employees of a given institution complexly or in selected categories pursuant to selected areas. The basis of the system is an original formula for the total calculation of an individual's performance.

The individual's results in the various areas are related to the average value achieved in the given area in the compared set, multiplied by the respective weighting coefficient of the area.

The goal of the presented paper is the introduction, development, description and presentation of a new and original system which will allow for the complex assessment of a chosen employee or group, and which has been applied at the Faculty of Mechanical Engineering, Slovak University of Technology in Bratislava in Bratislava, (STU BA).
\end{abstract}

JEL Classification Numbers: P48, DOI: 10.12955/cbup.v7.1378

Keywords: expert system, complex, individual, evaluation, performance, employee

\section{Introduction}

The known available systems of individual performance evaluation of employees make possible only partial employee evaluations, (Heneman, 1972), (Rynes, 2005), (Rafikul, 2006), (Shields, 2015). To our knowledge, no complex and objective individual assessment system is as yet available.

The proposed system has a number of specific properties which no one of the known systems, which guarantees originality in the given area, has. Parameters such as motivation, flexibility and complexity or universality belong here.

\section{Description of the system}

\section{Complexity}

The mathematical model is the sum of the proposed criteria that are multiplied by weight coefficients. The resultant performance of the employee is calculated according to the following relation (1), (Šooš, 2017).

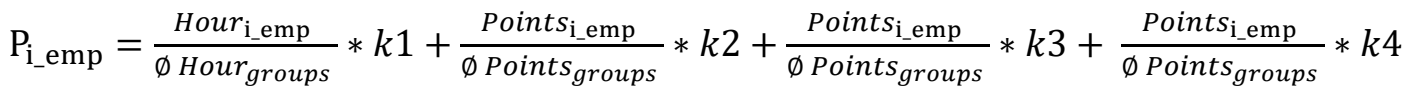

In the individual assessment of the employees of our institution, we selected performance areas such as pedagogy, science and research, publication outcomes and a final evaluation area known as "other activities" which are put into the evaluation by the head of the relevant department or workplace, according to precisely defined activities, Tab. 1. These values for the individual areas enter the system completely automatized on the basis of actually achieved outputs.

\begin{tabular}{|l|c|c|c|c|}
\hline Table 1: Performance areas and parameters of their significance \\
\hline Evaluated area & Pedagogy & Science and research & Publications & Other activities \\
\hline Significance coefficient & $\mathrm{k} 1$ & $\mathrm{k} 2$ & $\mathrm{k} 3$ & $\mathrm{k} 4$ \\
\hline Selected group & 0.35 & 0.35 & 0.2 & 0.1 \\
\hline Source: Šooš, 2017 &
\end{tabular}

\section{Pedagogy}

In connection with the function position of the teacher, pedagogical performances are evaluated for four reciprocally independent groups - professors, associate professors, specialist assistants and researchers. The evaluation of pedagogical performances in year $\mathrm{n}$, expressed in hours per week during a semester (h/week), is related to the two preceding calendar years, with the arithmetic average of performances in the evaluated years taken into account. Pedagogical performances are divided into direct pedagogical and indirect pedagogical processes. Lectures and exercises form parts of direct education. Their significance is differentiated according to their type and the degree of university education. Examining

\footnotetext{
${ }^{1}$ Faculty of Mechanical Engineering, Slovak University of Technology in Bratislava, lubomir.soos@stuba.sk
} 
bachelor works, semester projects, diploma works and pedagogical performances within the 3rd degree of study form parts of indirect education. The pedagogical performance of a teacher/researcher is the sum of his pedagogical performances within direct and indirect education, (Šooš, 2017).

Science and research

The science and research area takes into account the results achieved, particularly in project activities, and this by obtaining, leading and solving projects. A differentiated approach to the evaluation of projects according to importance, both domestic and international, is applied. Enterprising activity, contracts on work and the like are also calculated into the evaluation. A sample of the evaluated performances is presented in Table 2 .

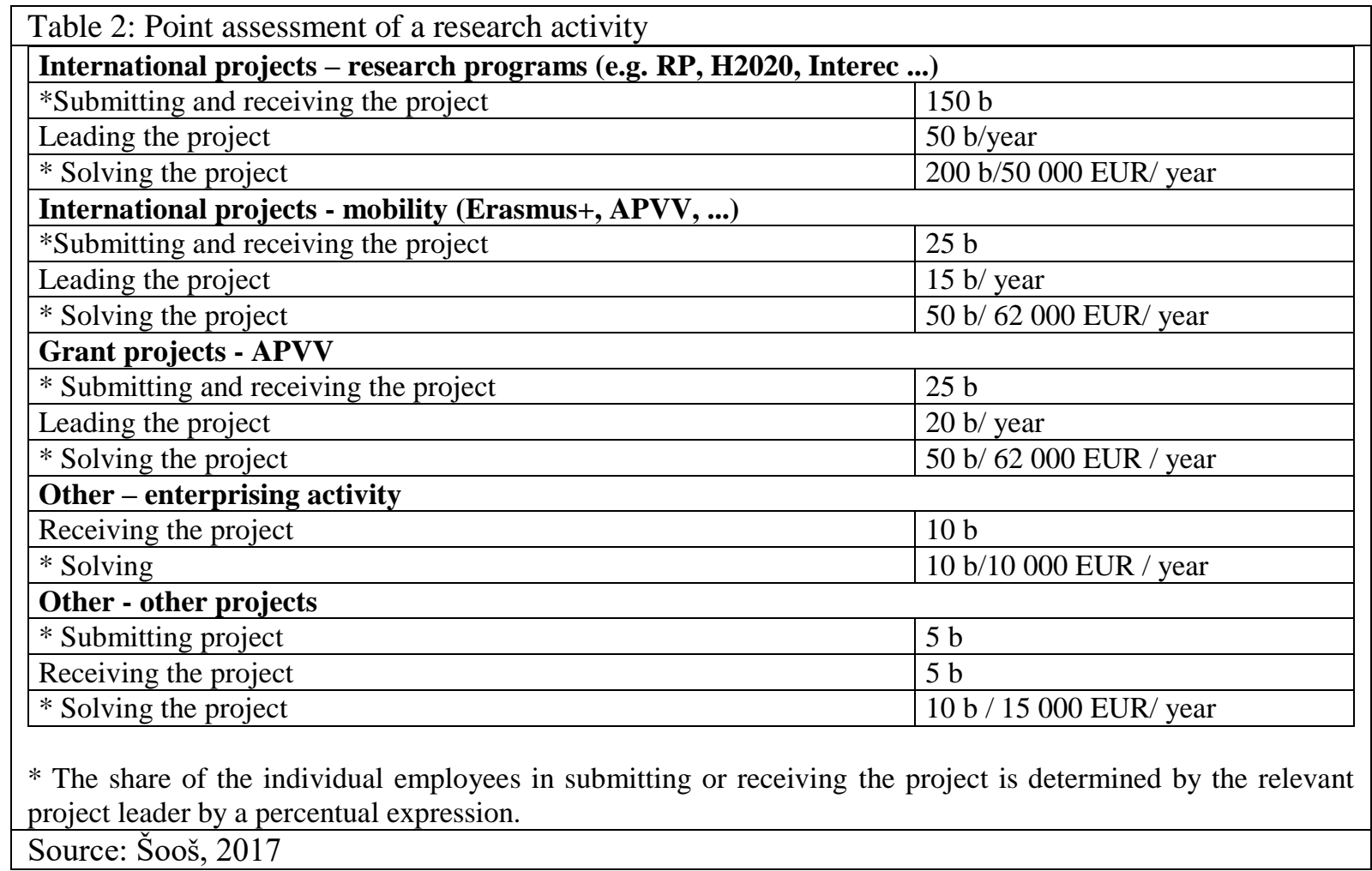

\section{Publications}

A quantitative assessment of performances rests to a maximal degree on the Ministry of Education, Science, Research and Sport of the Slovak Republic criteria of application for the assessment of publication performances as the bases for the purposes of distributing subsidies from the state budget to public universities. The proposed rules for the assessment of outputs in the area of publication activity also take into account the criteria of the Accreditation Commission applied in the process of accreditation of universities.

Points from the publications are determined by calculations according to the allocated financial resources which the institution receives from the Ministry for publishing individual types of publications. The highest financial valuation is given to Current Contents publications and patents or utility models. For example, for 2018 this was 5037 Eur. For this maximum sum are allocated 100 points. Other publication outputs have their point value allocated in proportion to this value. In the manner points for the individual types of publications were later automatically allocated. An example of allocated points is illustrated in Table 3, (Podklady k publikačnej činnosti, 2019). We added points for citations, Tab. 3. to the point system. The points are automatically calculated to the affected person after the registering of the work in AIS.

Other activities

The head of the institute evaluates all other activities that are not included in the first three areas. For the most part these are activities, which indirectly share in publicizing and enhancing the good name of the workplace or faculty. An example of points added for certain activities is illustrated in Table 4. 


\begin{tabular}{|l|c|}
\hline Table 3: Point assessments of research activities & Points \\
\hline Description & 47 \\
\hline $\begin{array}{l}\text { AAA, AAB, ABA - Scientific monographs and scientific studies in journals issued abroad or with } \\
\text { domestic publishers in world or other than world languages, }\end{array}$ & 21 \\
\hline ACA, ACB - University textbooks issued abroad and with domestic publishers & 100 \\
\hline $\begin{array}{l}\text { ADC, ADC, ADD - Scientific works in foreign and domestic current Contents journals in world or } \\
\text { other than world languages }\end{array}$ & 8 \\
\hline $\begin{array}{l}\text { AFA, AFC - Published invited papers from international scientific conferences in world or other } \\
\text { than world languages }\end{array}$ & 4 \\
\hline $\begin{array}{l}\text { AFB - Published invited papers from international scientific conferences in world or other than } \\
\text { world languages }\end{array}$ & 21 \\
\hline BCB, BCI - Textbooks for secondary and elementary schools, scripts and educational texts & 2 \\
\hline $\begin{array}{l}\text { AFE, AFF - Abstracts of published invited papers from international and domestic scientific } \\
\text { conferences }\end{array}$ & 100 \\
\hline AGJ - Authorial certifications, patents and discoveries & 21 \\
\hline BAA, BAB - Specialist book publications issued in foreign or domestic publishers & 100 \\
\hline $\begin{array}{l}\text { BDC, BDC, BDD, BDD - Specialist works in foreign and domestic Current Contents journals in } \\
\text { world or other than world languages }\end{array}$ & 1 \\
\hline $\begin{array}{l}\text { BDE, BDF - Scientific works in foreign and domestic other journals in world or other than world } \\
\text { languages }\end{array}$ & 47 \\
\hline BDM - Specialist works in foreign journals registered in the WOS or SCOPUS databases \\
\hline BDN - Specialist works in domestic journals registered in the WOS or SCOPUS databases \\
\hline $\begin{array}{l}\text { BEC - Specialist works in foreign and domestic reviewed proceedings in world or other than world } \\
\text { languages }\end{array}$ & 24 \\
\hline $\begin{array}{l}\text { Citations in foreign and domestic publications, registered in the WOS or SCOPUS databases' } \\
\text { citation indexes }\end{array}$ & 0 \\
\hline Citations in foreign and domestic publications, not registered in citation indexes & 2 \\
\hline Source: Podklady k publikačnej činnosti, 2019 & 1 \\
\hline
\end{tabular}

\begin{tabular}{|l|l|}
\hline Table 4: Point assessment of other activities \\
\hline Guarantor of a study program & $\begin{array}{l}30 \mathrm{p} / \text { year } \\
20 \mathrm{p} / \text { year / per } \\
\text { membership }\end{array}$ \\
\hline Membership in international specialist and scientific associations and organizations & $\begin{array}{l}10 \mathrm{p} / \text { year / per } \\
\text { membership }\end{array}$ \\
\hline Membership in domestic specialist and scientific associations and organizations & $\begin{array}{l}15 \mathrm{p} / \text { year / per } \\
\text { activity }\end{array}$ \\
\hline $\begin{array}{l}\text { Presentation of M.E,F, departments and faculty at exhibitions and public competitions } \\
\text { abroad }\end{array}$ & $\begin{array}{l}10 \mathrm{p} / \text { year / } \\
\text { a per activity }\end{array}$ \\
\hline $\begin{array}{l}\text { Presentation of M.E,F, departments and faculty at domestic exhibitions and public } \\
\text { competitions }\end{array}$ & $20 \mathrm{p} /$ per award \\
\hline Obtaining awards abroad & $10 \mathrm{p} /$ per award \\
\hline Obtaining domestic awards & $15 \mathrm{p} /$ case \\
\hline Organizing and running international scientific - conference guarantor & $10 \mathrm{p} /$ case \\
\hline $\begin{array}{l}\text { Organizing and running international scientific and specialist conferences - member of } \\
\text { a scientific or organizational commission }\end{array}$ & $10 \mathrm{~b} /$ case \\
\hline Organizing and running domestic scientific- conference guarantor & $5 \mathrm{p} /$ case \\
\hline $\begin{array}{l}\text { Organizing and running domestic scientific and specialist conferences - member of a } \\
\text { scientific or organizational commission }\end{array}$ & $15 \mathrm{p} /$ case \\
\hline $\begin{array}{l}\text { Membership in an editing council - international journal, journal with an international } \\
\text { editing council }\end{array}$ & $10 \mathrm{p} /$ case \\
\hline Membership in an editing council - domestic journal & $10 \mathrm{p} /$ case \\
\hline Assessments and textbook reviews, projects, articles, papers-international, domestic & \\
\hline Source: Šooš, 2018 & \\
\hline
\end{tabular}

\section{Motivation}

The basic starting point for the proposal for a new system was to evaluate transparently and to positively motivate the workers in a given group.

In the proposed formula (1) the values of the workers in an evaluated group are compared. By receiving a numerical value of ' 1 ' the assessed individual receives the average of the evaluated group. The basis 

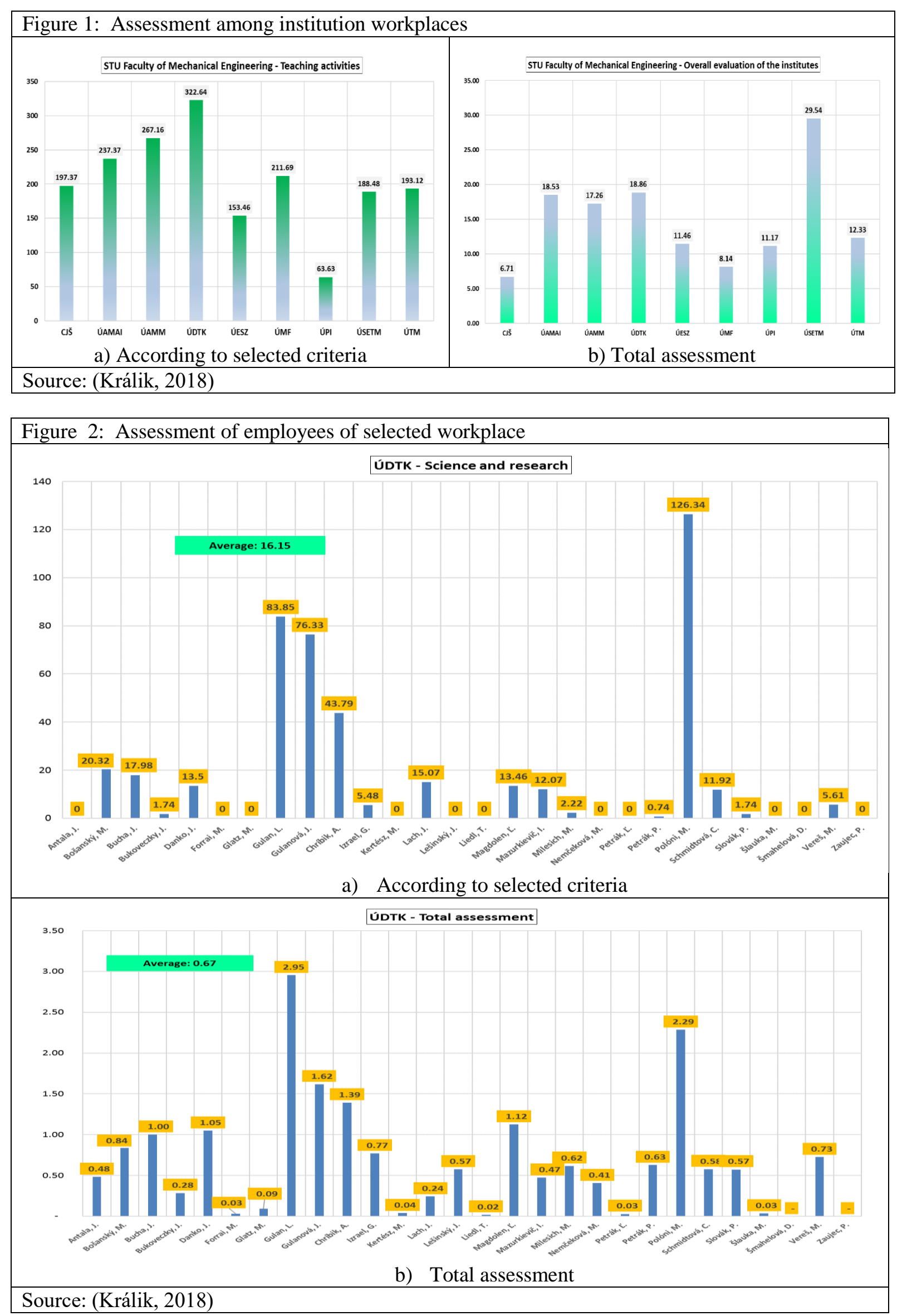
of the proposed system is so to motivate employees to increase their point values and to be better than the average. Employees with point assessments higher than the average are further motivated by

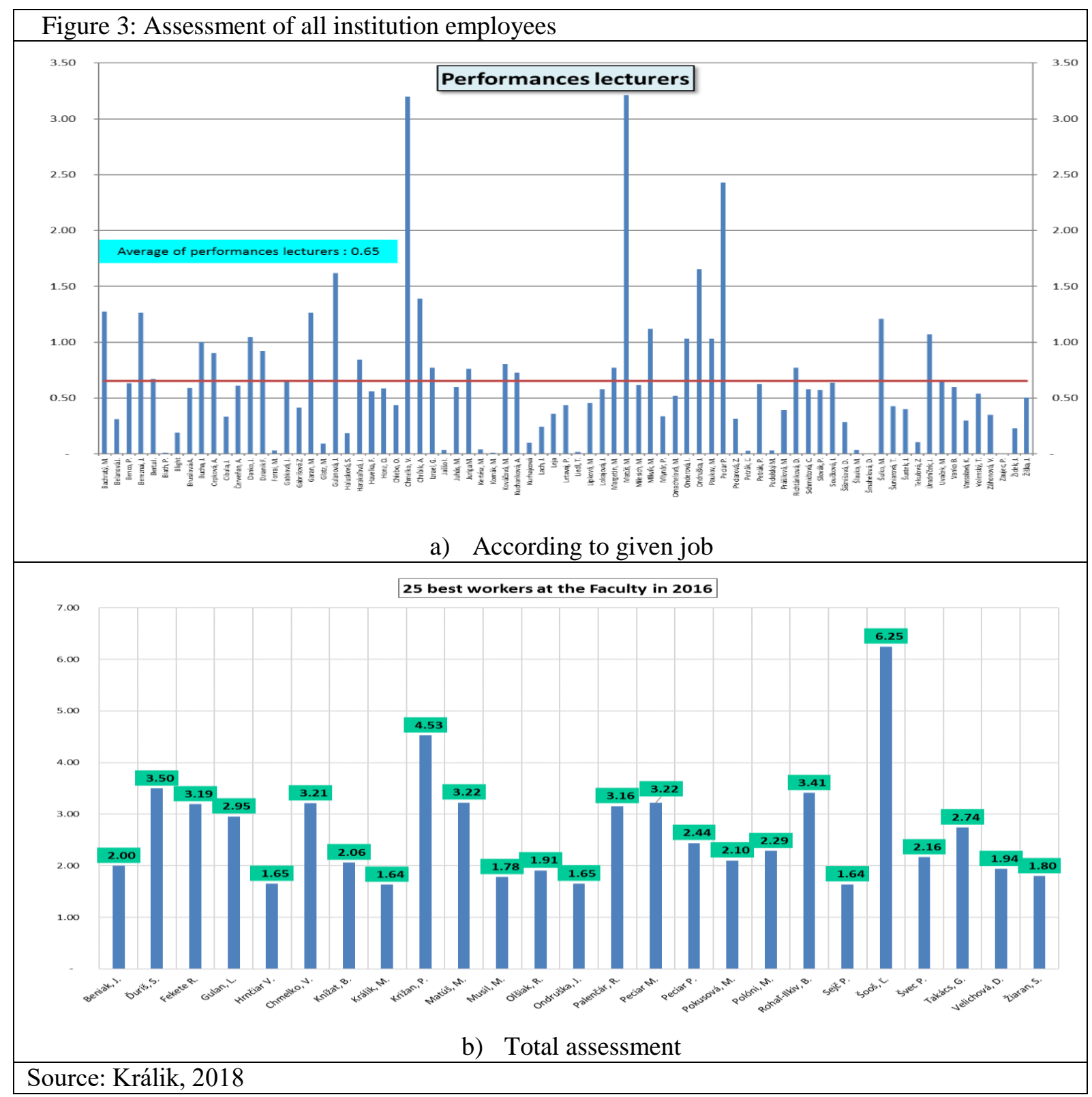

personal assessments. The beauty of the motivational factor lies in the fact that when several employees from a given group want to achieve better than the average, the total average of the group in the nominator increases. In this way the performance of the given group and so of the whole institution increases in the final analysis.

\section{Universality}

The system allows for the mutual comparison of the individual workplaces (fig. 1), it also allows for the comparison of the employees of a selected workplace (fig. 2), as well as of the whole group of employees of a given institution (fig. 3). We can compare people according to profession in groups of researchers or pedagogues, according to the scientific/pedagogical title achieved, or even individual employees over a period of several years, (Králik, 2018).

\section{Autodiagnostics}

The expert system also allows reverse analysis of the individual. On the basis of a simple comparison apparatus, the individual can determine where they must improve or by how much they must make up for in another area when they do not fulfill one of the other areas. A frequent question from employees 
is by how much they must exceed these other areas if they do not achieve the required average in one or more categories. Accordingly, we worked out an auto-reverse mechanism into the system, (Velichova, 2018).

So how can an individual achieve an average performance when they do not fulfill a certain category? Let us assume that all employees obtain an average assessment by the head of an institute, so $\mathrm{t}=1$ and the equation (1)

$$
\mathrm{P}_{\mathrm{i} \_ \text {emp }}=\mathrm{x} * k 1+\mathrm{y} * k 2+\mathrm{z} * k 3+\mathrm{t} * k 4
$$

- takes the form

$$
x * 0.35+y * 0.35+z * 0.2=0.9
$$

- if the employee does not teach, $\mathrm{x}=0$ and the equation (2) takes the form

$$
y * 0.35+z * 0.2=0.9
$$

- if the employee does not conduct research, $y=0$, only publishes, then

$$
z * 0.2=0.9 \quad \Rightarrow z=4.5
$$

So their performance in publications must be 4.5 times greater than the average;

- if the employee does not publish, (then $\mathrm{z}=0$ ) and does only science, then the equation (4) takes the form

$$
y * 0.35=0.9 \Rightarrow \mathrm{y}=2.57
$$

So their performance in science must be 2.57 times greater than the average. In the case that the employee only does pedagogy and does not undertake research. Therefore, their performance in pedagogy must be 2.57 times greater than the average.

\section{Conclusion}

The goal of the prepared paper was to present an original system for the individual assessment of employees. The system is currently in operation for the second year. At the moment there are about 15,000 automatically input values in the system. The system makes possible a complex assessment of the selected employee, chosen workplace or the entire institution according to given areas, i.e. pedagogics, science and research, publications and special area. The test operation at the Faculty of Mechanical Engineering, STU BA has demonstrated its originality and transparency, as well as the opportunity to achieve the desired outputs with great variety and effectiveness.

\section{Acknowledgements}

The research presented in this paper is an outcome of project No. APVV-15-0704. "Split-Core Trainer Strengthening System for athletes and untrained individuals with functional back pain." funded by the Slovak Research and Development Agency.

\section{References}

Heneman, H. G., \& Schwab, D. P. (1972). Evaluation of research on expectancy theory predictions of employee performance. Psychological Bulletin, 78(1), 1-9.

Rafikul, I., Shuib, M. R.: Employee Performance Evaluation by the AHP: A Case Study. Asia Pacific Management Review, DOI: 10.6126/APMR.2006.11.3.04 (2006/ 06 / 01), P163 - 176

Rynes, SL., Gerhart, B., Parks - Annu, L., : Personnel psychology: Performance evaluation and pay for performance. Rev. Psychol., 2005 - annualreviews.org.

Shields, J., Brown, M., Kaine, S ., Dolle-Samuel, C.: Managing employee performance \& reward: Concepts, practices, strategies - 2015 - books.google.com

Šooš, L. a comp. Expertný systém hodnotenia výkonov, [software], Bratislava, SjF STU, 2017.

Podklady k publikačnej činnosti (2019). Retrieved from https://www.minedu.sk/rozpis-dotacii-zo-statneho-rozpoctuverejnym-vysokym-skolam-na-rok-2019

Králik, M. \& Jerz, V. The measurement of residual stresses in the surface layers of the materials after machining. In Materials Science Forum. Vol. 919, (2018), s. 345-353. ISSN 0255-5476 (2017: 0.180 - SJR, Q3 - SJR Best Q), In: SCOPUS: 2-s2.0-85045419800.

Komák, M. \& Králik, M. Path generation by avoiding obstacles using the intersection of bodies. In TEM Journal. Vol. 7, iss. 1 (2018), s. 232-237. ISSN 2217-8309. In: SCOPUS: 2-s2.0-85042628450.

Velichová, D. Autodiagnostika, ESHV, [pracovné listy], Bratislava, SjF STU, 3p., 2018. 